\title{
Dosing patterns of canakinumab in patients with Cryopyrin-Associated Periodic Syndromes (CAPS): A comparative analysis of a study in Western versus Japanese patients
}

B Bader-Meunier ${ }^{1 *}$, P Hachulla ${ }^{2}$, J Kuemmerle-Deschner ${ }^{2}$, M Gattorno ${ }^{2}$, N Patel ${ }^{2}$, R Preiss ${ }^{2}$, K Lheritier ${ }^{2}$, T Imagawa ${ }^{2}$, R Nishikomori ${ }^{2}$, H Takada², T Heike², T Hara $^{2}$, S Yokota ${ }^{2}$

From 18th Pediatric Rheumatology European Society (PReS) Congress

Bruges, Belgium. 14-18 September 2011

\section{Background}

CAPS is an orphan auto-inflammatory disease, generally diagnosed in childhood that requires life-long treatment. Canakinumab, a fully human anti-IL-1b antibody, has previously demonstrated rapid, complete and sustained response in CAPS patients.

\section{Aim}

To compare dosing patterns of canakinumab in pediatric and adult CAPS patients of a predominantly Western population (WP) vs Japanese patients (JP).

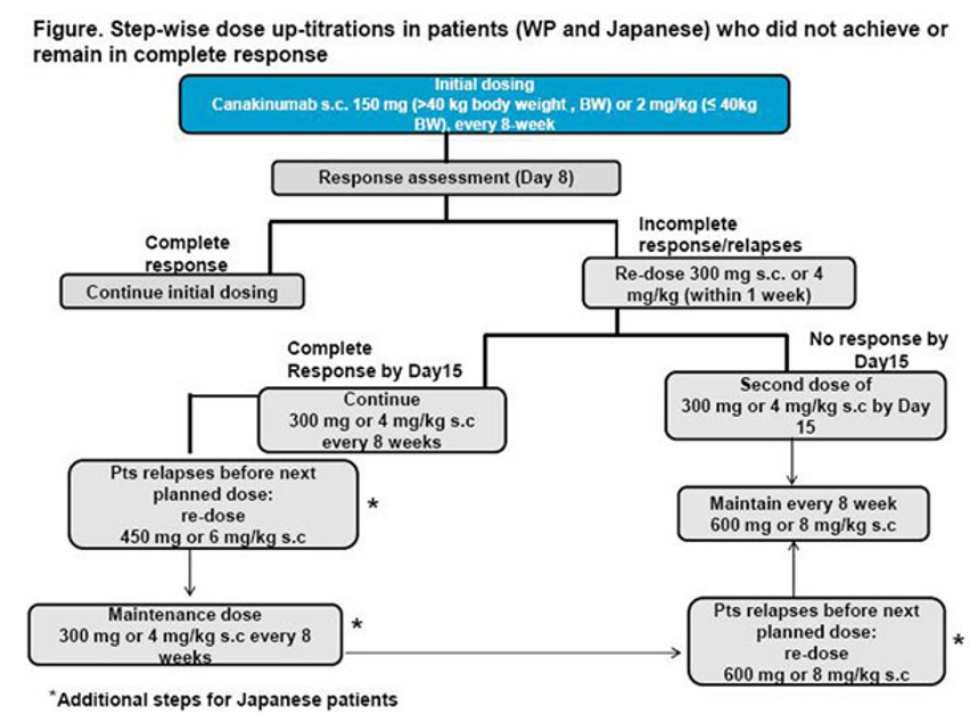

Figure 1 Step-wise up-titrations in patients (WP and Japanese) who did not achieve or remain in complete response

\footnotetext{
* Correspondence: brigitte.bader-meunier@nck.aphp.fr

'Department of Pediatric Immunology and Rheumatology, Université ParisDescartes and Hôpital Necker-Enfants Malades, Assistance Publique Hôpitaux de Paris, Paris, France

Full list of author information is available at the end of the article
} 
Table 1 Canakinumab doses by phenotypes

\begin{tabular}{lllll}
\hline $\begin{array}{l}\text { Phenotype }(\mathrm{n}=\mathrm{WP} / \\
\text { JP) }\end{array}$ & Wester population & Japanese population & \\
\hline & $\begin{array}{l}\text { Adult Mean/median }(\mathrm{mg}) \\
(\mathrm{N}=136)\end{array}$ & $\begin{array}{l}\text { Pediatrics }{ }^{2} \text { Mean/mdeian }(\mathrm{mg} / \mathrm{kg}) \\
(\mathrm{N}=29)\end{array}$ & $\begin{array}{l}\text { Adult }{ }^{1} \text { Mean/median }(\mathrm{mg}) \\
(\mathrm{N}=8)\end{array}$ & $\begin{array}{l}\text { Pediatrics } \\
(\mathrm{N}=11)\end{array}$ \\
\hline MWS (103/7) & $200 / 150$ & $5.5 / 4.0$ & $225 / 150$ & $6.0 / 6.0$ \\
NOMID (32/11) & $299 / 150$ & $5.8 / 4.0$ & $300 / 225$ & $5.5 / 6.0$ \\
FCAS (30/0) & $189 / 150$ & $2.7 / 2.0$ & - & - \\
\hline
\end{tabular}

\section{Methods}

Canakinumab s.c. $150 \mathrm{mg}$ (if $>40 \mathrm{~kg}$ ) or $2 \mathrm{mg} / \mathrm{kg}$ (if $\leq 40$ $\mathrm{kg}$ ) was dosed every 8 weeks. Step-wise up-titrations in dose were allowed in patients who did not achieve/ remain in complete response (CR, Figure 1).

\section{Results}

Median duration of treatment was 414 (29-687) days in WP and 337 days (59-373 days) in JP. In the WP, CR was achieved in 85/109 (78\%) canakinumab-naive patients. $127 / 141$ (90\%) evaluable patients remained in CR throughout the study. 47/166 patients in WP and $11 / 19$ patients in the Japanese study were pediatrics. $36.2 \%$ vs $81.8 \%$ (WP vs JP) of children received uptitrated and/or more frequent doses. Higher median doses were required in pediatric patients in the JP compared with WP to control MWS and NOMID (Table 1). $13 \%$ vs $45 \%$ (WP vs JP) of the children received the maximum permitted dose. None of those children showed an unusual type or frequency of adverse events.

\section{Conclusions}

Increased doses of canakinumab were equally efficacious in patients of a WP and Japanese population comprising different CAPS phenotypes without evidence of a change in AE profile. These data suggest that children and patients with more severe CAPS phenotypes, irrespective of ethnicity, require differential dosing.

\section{Author details}

${ }^{1}$ Department of Pediatric Immunology and Rheumatology, Université ParisDescartes and Hôpital Necker-Enfants Malades, Assistance Publique Hôpitaux de Paris, Paris, France. ${ }^{2}$ On behalf of the Canakinumab D2306 and D2308 study group.

Published: 14 September 2011

\section{doi:10.1186/1546-0096-9-S1-P12}

Cite this article as: Bader-Meunier et al:: Dosing patterns of canakinumab in patients with Cryopyrin-Associated Periodic Syndromes (CAPS): A comparative analysis of a study in Western versus Japanese patients. Pediatric Rheumatology 2011 9(Suppl 1):P12.

Submit your next manuscript to BioMed Central and take full advantage of:

- Convenient online submission

- Thorough peer review

- No space constraints or color figure charges

- Immediate publication on acceptance

- Inclusion in PubMed, CAS, Scopus and Google Scholar

- Research which is freely available for redistribution

Submit your manuscript at www.biomedcentral.com/submit 